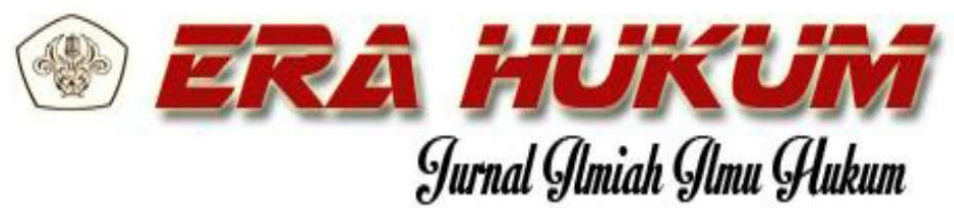

\title{
KEPASTIAN HUKUM MENGENAI PERBEDAAN ANTARA PUTUSAN MAHKAMAH AGUNG DAN PUTUSAN MAHKAMAH KONSTITUSI TERKAIT PENCALONAN PERSEORANGAN PESERTA PEMILU ANGGOTA DPD
}

\begin{abstract}
Rasji
(Dosen Fakultas Hukum Universitas Tarumanagara. Meraih Sarjana Hukum pada Fakultas Hukum Universitas Tarumanagara, Magister Hukum pada Fakultas Hukum Universitas Indonesia)

(E-mail: rasji@ fh.untar.ac.id)
\end{abstract}

\section{Cinthia}

(Mahasiswa Program S1 Fakultas Hukum Universitas Tarumanagara)

Received: 22 April 2019; Accepted: 29 Mei 2019; Published: 10 Juni 2019

\begin{abstract}
Indonesia is a country based on the law (rechstaat) whose basis is stated in Article 1 Paragraph (3) of the UUD NRI 1945. The essential principles of the rule of law based on Article 24 Paragraph (1) of the UUD NRI 1945 are the guarantee of the organizer of the power of an independent judicial institution without interference from other parties to hold a court to uphold law and justice. Ideally, the results of the two institutions' decisions do not cause problems in society. However, the results of the decisions of the two institutions are still found differently regarding the issue of nominating individual participants in the members of the Regional Representatives Council. Any other way, the results of the Constitutional Court ruling prohibited members of the Regional Representatives Council who were still in the position of administrators of political parties. Meanwhile, the decision of the Supreme Court allows candidates for members of the Regional Representatives Council who are still in the position of managing political parties. In this study, the researcher will examine the differences between the Supreme Court's decision and the Constitutional Court's decision regarding the nomination of individual participants in the Regional Representatives Council by using normative legal methods and conducting interviews as supporting data. The results of the study revealed that based on the legal basis and authority of the institution, the verdict that had legal certainty regarding the nomination of individual participants in the Regional Representatives Council election was the decision of the Constitutional Court.
\end{abstract}

Keywords: Constitutional Court, Elections, Legal Certainty, Supreme Court

\section{PENDAHULUAN}

\section{A. Latar Belakang}

Negara Indonesia merupakan salah satu negrra yang berlandakan atas hukum (rechtstaat), yang memiliki dasar pijakan tercantum di dalam Pasal 1 Ayat (3) UUD NRI 1945. Dalam pasal teresbut dapat dikatakan bahwa "Negara Indonesia adalha negara hukum". Indonesia menerrima hkum sebagai ideologi untuk menciptakan suattu 
ketertiban, keamanan, keadilan dan kesejahteraan bagii setiap warga negrra Indonesia. Arti negar hukum itu sendiri pada hakikatnya berakar dari konsep teoir kedaulatan hukum, di mana yang pada prinsipnya menyatakna bahwa kekuasaan tertinggi di dalam suatu negara adalah hukum. Oleh karena itu, maka seluruh alat perlengkapna negara apapun namanya termasuk warga negara harus tunduk dan patuh serta menjuunjung tinggi pada hukum tanpa adanya pengecualian. Krabe mengemukakan bahwa suatu negara sebagai pencipta dan penegak hukum dalam seluruh kegiatannya, dan harus tunduk pada suatu hukum yang berlaku adanya. Dalam pengertian ini hukum membawahkan negara. berdasarkan pengertiannya, hukum itu bersumber dari suatu kesadaraan hukum rakyat. Oleh sebab itu, hukum memiliki wibawa yang tidak akan berkaitan dengan seseorang (impersonal). ${ }^{1}$

Salah satu dar prinsip terpenting dari sebuah negara hukum adalah yaitu dengan adanya suatu jaminan penyelenggara kekuasana lembaga peradilan yang merdeka, bebas dari segala macam camput

${ }^{1}$ B. Hestu Cipto Handoyo, Hukum Tata Negara Indonesia, (Yogyakarta: Universitas Atma Jaya Yogyakarta, 2009), hal. 16-17. tangam dan intervensi dari pihak pihak lembaga lain. Tujuannya dari adanya fungsi tersebut untuk menegakn suatu ketertiiban, keadilan, kebenaran dan juga kepastian hukum yang berlangsung sahingga dapat mampu memberikan pengayoman pada seluruih masyarakaty. Pemahaman dari atas suatu peradilan yang merdeka tidak terlepas dari teori teori pemisahan kekuasaan yang dikemukakan oleh John Locke dan Montesquieu. Tujuan dan perlunya pemisahan kekuasaan adalahh bertujuan untuk menjamim adanya suatu kebebasan politik bagi seluruh tiap warga negara. ${ }^{2}$ Secara spesifik, kekuasaam kehakiman yang merdeka diatur di dalam Pasal 24 Ayat (1) UUD NRI 1945 yanb menyatakan kekuasaan kehakiman merupakam kekuasaam yang merdeka untuk menyelenggarakan peradilan guna menegakkan hukun dan keadilan. Kekuasaan kehakiman di Indonesia dilakukan oleh Mahkamah Agung serta peradilan dibawahnya dalam lingkungan; Peradilan Umum, Peradilan Tata Usaha

\footnotetext{
${ }^{2}$ Sirajuddin dan Winardi, Dasar-Dasar Hukum Tata Negara Indonesia, (Malang: Setara Press, 2015), hal. 131.
} 
Negara, Peradilan Agama, Peradilna Militer, dan oleh Mahkamah Konstitusi. ${ }^{3}$

Di Indonesia terdapat dua lembago peradilan, seperti Mahkamah A gung dan Mahkamah Konstitusi yang telah diberikan kewenangan oleh UUD NRI 1945 untuk melakukna pengujain peraturran perundang undangan dengan objek pengujian yang berbeda beda. Kedudukan Mahkamah Agung adalah sejajar dengan kedudukan dari Mahkamah Konstitusi, namun dengan tugas dan kewenangan yang berbeda beda. Mahkamah Agung mempunyai tugsa dan kewenangan yang berupa melakukan pengujian - pengujian dari peraturan peraturan perundangan di bawah undanggundang, sedangkam tugas Mahkamah Konstitusi melakukn pengujian pda undangg - undang terhadap UUD NRI 1945.

Berdasarkan Pasal 7 Ayat (1) Undang-Undang Nomor 12 Tahun 2011 tentang Pembentukan Peraturan Perundang Undangan menyatakan bahwai tata urutan peraturan perundang - undangan di Indonesia adalah:

1. Undang-Undang Dasar Negara Republik Indonesia Tahun 1945;

\footnotetext{
${ }^{3}$ Ni'matul Huda, Hukum Tata Negara Indonesia, (Jakarta: Raja Grafindo, 2005), hal. 197.
}

2. Ketetapan

Majelis;

Permusyawaratan Rakyat;

3. Undang-Undang / Peraturan Pemerintah Pengganti UndangUndang;

4. Peraturan Pemerintah;

5. Peraturan Presiden;

6. Peraturanl Daerah Provinsi ; dan

7. Peraturan Daerah Kabupaten/Kota.

Dari pasal tersebut terlihat bahwa UUD NRI 1945 berada pada posisi tertinggi dalan urutan peraturan perundangundangan di Indonesia. Oleh sebab itu, konsekuensinya adalah peraturan yagn lebih rendah tidak boleh bertentangna dengan peraturan yang lebih tinggi Dalam hal menjamin penyusunan peraturan perundang-undangan tidak bertentangan dengan konstitusi, maka haruslah dilakukan suatu mekanisem untuk mengawasinya melalui hak menugji. Penguijan peraturan perundang -undangan oleh kekuasaan kehakiman atau di kalangan akademis maupun praktisi hukum biasa disebut judicial review. Pada umumnya, judicial review dilakukan oleh Mahkamah Agung dan Mahkamah Konstitusinya, hanya saja objek pengujiannya yang berbeda. Setiap putusan judicila review dari 
Mahkamah Agung maupun dari Mahkamahl Konstituis idealnya tidak menghasilkan putusan yang berbeda. Sebab, dengan adanya hasil judicial review yang berbeda dari lembaga yudikatif tersebut, maka dapat menimbulkan permasalahan baru dalam masyarakat. Artinya, suatu kualisas putusan hakim mempunyai pengaruh penting pada lingkungan masyarakat dan berpengaruh pada kewibawaan dan kredibilitas lembaga pengadialn itu sendiri. Namun dalam praktik pelaksanaannya di Indonesia masih banyak ditemukan beberapa perbedaan antara hasil hasil putusan Mahkamah Agug dan putusan Mahkamah Konstitusi yang menimbulkan permasalahan dalam masyarakat.

Berkenaan dengan permasalahan di atas, pada tahun 2018 silam di Indonesia kembali terdapat hasil putusan yang berbeda dari hasil judicial review antara Mahkamah Agung dna putusan Mahkamah Konstitusi terkait pencalonan perseorangan peserta pemilu anggota DPD. Di satu sisi, hasil judicial review dari Mahkamah Agung melahirkan putusna dengan nomor 65P/HUM/2018 yang memperbolehkan calon anggota DPD yang berasla dari kepengurusan partai pollitik. Di sisi lain, putusan Mahkamah Agung tersebut jelas berbeda dengan Putusan Nomor 30/PUU$\mathrm{XVI} / 2018$ yang melarang calon anggota DPD berasal dari kepengurusan partai politik. Dengan lahirnya 2 (dua) putusan yang berbeda tersebut menyebabkan ketidakpastian hukum dalam masyarakat. Masyarakat bingung putusan mana yang harus diikuti dan yang memiliki kepastian hukum. Oleh sebab itu, judul dari penulisan ini adalah "Kepastian Hukum Mengenai Perbedaan Antara Putusan Mahkamah Agung Dan Putusan Mahkamah Konstitusi Terkait Pencalonan Perseorangan Peserta Pemilu Anggota DPD”.

\section{B. Perumusan Masalah}

Berdasrakan uraian latalr belakang di atas, maak permasalahannya adalah bagaimana kepastian hukum mengenai perbedaan antara putusan Mahkamah Agung dan putusan Mahkamah Konstitusi terkati pencalonan perseorangan peserta pemilu anggota DPD?

\section{Metode Penelitian \\ 1. Jenis penelitian \\ Jenis penelitian yang digunakan dalam penelitian ini adalah penellitian}


hukum normatif atau biasa disebut dengan penelitian untuk keperluan akademis. ${ }^{4}$ Digunakannya metode penelitian normatif karena di dalam penulisan ini dilakukan penelitian dengan menggunakan beberapa peraturan peundang-undagnan yang selanjutnya dijelaskan dengam menggunakan kata-kata maupun pernyataanpernyataan.

2. Jenis dan Teknik Pengumpulan, Data Jensi data yagn digunakan adalah data sekunder. Dataa sekunder berarti dats tersebut diperoleh dan dikumpulkan peneliti dari berbagai sumber yang ada. Teknik pengumpulan data yang digunakan dalam penelitian ini adalah menggunakan studi dokumem atau studi kepustakaan. Jenis teknik pengumpulan ini merupakan suatu alar pengumpulan bahan hukum yang dilakukan dengan cara menggunakan bahan hukum tertulsi dan juga mempergunakam contemt analysist. ${ }^{5}$

\section{Pendekatan Penelitian}

Dalam penelitian ini, maka perlu digunakannya sebuah metode pendekatan yang berkaitam degnan permasalahan dalam penelitian. Dengan adanya metode

\footnotetext{
4 Peter Mahmud Marzuki, Penelitian Hukum, (Jakarta: Kencana Prenada Media Group, 2016), 59.

${ }^{5}$ Ibid., hal. 181.
}

pendekatan tersebut, maka peneliti akam mendapatkan informasi dari berbagai aspek mengenail isu atau masalah yagn sedamg dcoba unutk diicari jawabanya. Metode pendekatan yang digunakan dalam penelitian ini adalah pendekatam udaangundang (statue approach), yang dilakukam degnan cara menelaah semua undang undang dan regulasi yang bersangkotan dengan isu hukum yang sedang ditangani. Selanjutnya, hasil dair telaah tersebtu merupakan suatu argument untuk memecahkan isu yang dihadapi. ${ }^{6}$

\section{Spesifikasi Penelitian}

Spesifikasi penelitiam yang digunakan dalam penelitian ini adalah penelitian preskriptif. Preskriptif berarti memberikam preskripsii mengenau apa yang seyogianya ${ }^{7}$ Berkaitan dengan objek penelitian dalam penelitian ini, maka spesifikasi penelitian ini bertujuan untuk mendeskripsikan tentang analisis kepastian hukum mengenai perbedaan antara putusanl Mahkamah Agung dna putusan Mahkamah Konsittusi teakait pencalonan perseorangan peserta pemilu anggota DPD.

\footnotetext{
${ }^{6}$ Ibid., hal. 133.

${ }^{7}$ Ibid., hal. 181.
} 


\section{Teknik Analisis Data}

Secara sederhana, analisis data merupakan suatu kegiatan untuk memberikan telaah dan kemudian dibuat sebuah kesimpulan terhadap hasil dari penelitian dengan pikiran sendiri dan bantuan teori. ${ }^{8}$ Dalam penelitian ini, maka digunakan teknik analisis data deduktif, yaitu analisis dengan cara menjelaskan suatu hal dari yang bersifat umum, kemudian menariknya menjadi suatu kesimpulan yang lebih khusus berdasarkan sumber penelitian yang ada.

\section{PEMBAHASAN}

\section{A. Analisis Dasar Hukum Penaclonan Perseorangan Peserta Pemilu Anggota DPD}

Berdasarkan Pasal 1 angka 31 UndangUndang No 7 Tahun 2017 tentang Pemilihan Umum, perseorangan peserta pemilu anggota DPD ialah perseorangan yang telah memenuhi persyaratan sebagai peserta pemilu anggota DPD. Jadi pencalonan perseorangam peserta pemilu anggota DPD

8 Tunjung Herming Sitabuana (b), "Penyelesaian Masalah Diskriminasi Terhadap Etnis Cina (Studi Tentang Perkembangan Politik Hukum di Bidang Kewarganegaraan Republik Indonesia)", (Ringkasan Disertasi Doktor, Universitas Diponegoro, 2011), hal. 183. merupakan suatu proses mencalonkan perseorangan yang telah memenuhi seluruh persyaratan sebagai peserta pemilu anggota DPD. Keseluruhan persyaratan yang dimaksud sesungguhnya telah diatur secara jelas dalan Undang-Undang Nomor 7 Tahun 2017 tentang Pemilihan Umum dn juga dalam Pearturan Komisi Pemilihan Umum Nomor 26 Tahun 2018 tentang Perubahan Kedua Atas Peraturam Komiis Pemilihan Umum Nomor 14 Tahun 2018 tentang Pencalonam Perseoranganl Peserta Pemilu Anggota DPD.

Seseorang dapat dikatakan bisa menjaid calon peserta pemilu anggotla DPD, jika telah memenuhi lpersyaratanpersyaratan sebagaimana yang telah diatur dalam undang-undang dan peraturan tersebut. Jika tidak memenuhi persyaratan tersebut, maka orang tersebut tidak dapat mencalonkam dirinya sebagai calon anggota DPD. Persyaratam yang tercantum dalan Undang-Undang Nomor 7 Tahun 2017 tentang Pemilihan Umum dan dalan Peraturan Komisi Pemilihan Umum Nomor 26 Tahun 2018 tentang Perubahan Kedua Atsa Peraturan Komisi Pemilihan Umum Nomor 14 Tahun 2018 tentang Pencalonan Perseorangan Peserta Pemilu 
Anggota DPD memiliki persyaratan yang serupa. Persyaratan yang tercantum di dalamnya adalah sebagai berikut:

a. WNI yang telah berumur 21 (dua puluh satu) tahun atau lebih terhtung sejak penetapan DCT anggota DPD;

b. Bertakwa lkepada Tuhan Yang Maha Esa;

c. Bertempatl ltinggal dil lwilayah NKRI;

d. Dapatl lberbicara, lmembaca, ldan/atau lmenulis dalam bahasa Indonesia;

e. Berpendidikan paling rendah tamat sekolah menengah atas, madrasah laliyah, sekolah menengah kejuruan, madrasah aliyah kejuruan, atau sekolah lain yang sederajat;

f. Setial kepada Pancasila, UUD NRI 1945, NKRI, dan Bhinneka Tunggal Ika;

g. Tidak pernah sebagai terpidana berdasarkan putusan pengadilan yang telah memperoleh kekuatan hukum tetap;

h. Bagil lterpidana yangl ltidak menjalanil pidana di dalam penjara meliputi:

1) Terpidana karena kealpaan ringan (culpa levis); atau

2) Terpidana karena alasan politik, wajib secara terbuka dan jujur mengemukakan kepada publik bahwa yang bersangkutan sedang menjalani pidana tidak di dalam penjara;

i. pemidanannya, secara kumulatif, wajib lmemenuhi syarat secara terbuka dan jujur mengemukakan kepada publik dan bukan sebagai pelaku kejahatan yang berulang;

j. Bukan mantan terpidana bandar narkoba, kejahatan seksual terhadap anak, atau korupsi;

k. Sehat jasmani dan rohani, dan bebas dari penyalahgunaan narkotika, psikotropika dan zat adiktif;

1. Terdaftar sebagai pemilih;;

m. Bersedia bekerja penuh lwaktu;;

n. Mengundurkan diri sebagai kepada daerah, wakil kepala daerah, kepala ldesa dan perangkat desa, badan permusyawaratan desa, ASN, anggota TNI, anggotal kepolisian NRI, dan tidk merankap jabatan sebagai direksi, komisaris, dewan pengawas dan karyawan BUMN, dan/atau BUMD, dan/atau badan usaha milik daerah, dan/atau badan usaha milik desa, atau badan lain yang anggarannya bersumber dari keuangan negara, yang dinyatakan 
dengan surat pengunduran diri yang tdak dapat ditarik kembali;

o. Mengundurkan diri sebagai penyelenggara serta panitia pemilu dan panitia pengawas yang dinyatakan dengan surat pengunduran diri yang ltidak dapat ditarik kembali

p. Bersedia untuk tidak praktik sebagai akuntan publik, advokat, notaris, PPAT, dan/atau tidak melakukan pekerjaan penyedia barang dan jasa yang berhubungan dengan keuangan negara serta pekerjaan lain yang dapat menimbulkan konflik kepentingan dengan tugas, wewenang, dan hak sebagai anggota DPD sesuai dengan ketentuan peraturan perundang-undang (termasuk tidak merangkap jabatan sebagai pengurus partai politik);

q. Mencalonkan hanya 1 (satu) lembaga perwakilan;.

r. Mencalonkanl hanya 1 (satu) daerah pemilihan;.

s. Mendapat dukungan minimal dari pemilih di daerah pemilihan yang bersangkutan; dan.

t. Telah melaporkan kekayaannya kepada instansi yang berwenang memeriksa laporan kekayaan penyelenggara negara .

Proses pencalonan perseorangan peserta pemilu anggota DPD di Indonesia dilaksakan secara demokrasi. Demokrasi di Indonesia tidak dapat dipisahkan karena Indonesia merupakan negara hukum dan keduanya saling berkaitan dan merupakan suatu prasyarat bahwa negara hukum pastilah negara yang demokrasi. Secara tataran konsepsi, demokrasi mengutamakan adanya dan pentingnya pluralisme dalam masyarakat. Selain itu, demokrasi tidak akan terwujud jika disertai sikpa mau benar sendiri. Demokrasi mewajibkan sikap saling percaya danl saling menghargai antara warga masyarakat. Demokarsi merupakan suatu gagasan maupun pandangan hidup yang mengutamakam persaman hak dan kewajiban serta perlakuan yang sama bagi warga negara.

Berkaitan dengan gagasan demokrasi yang mengutamakan persamaan hak dan kewajiban serta perlakuan yang sama bagi semua warga negaranya, maka dalam hal ini 
para anggota DPD dalam kepengurusannya pun memiliki beberapa hak dan kewajibannya masing-masing. Masing-masing hak dan kewajibannya telah diatur secara rinci dalma udang-undang yang bersangkutan. Dalam Pasal 258 Undang-Undang Nomor 17 Tahun $2014 \quad$ tentang Majelis Permusyawaratan Rakyat, Dewan Perwakilan Rakyat, Dewan Perwakilan Daerah, dan Dewan Perwakilan Rakyat Daerah (yang selanjtnya disebut dengan UU MD3) disebutkan bahwa kewajiban dari anggota DPD ialah memegang teguh serta mengamalkan Pancasila, melaksanakan UUD NRI 1945 serta mentaati praturan perudang-undngan, menpertahankan serta memelhara kerukunam nasiional dan keutuhan NKRI, mendahulukan kepentingan negara di atas kepentingan pribadi, kelompok, golongan dan daerah, menaati prinsip demokrasi dalma penyelenggaraan pemerintah negara, menaati tata tertib dan kode etik, menjaga etika dan norma dalam hubungan kerja dengan lembaga lain, menampung dan menindaklanjuti aspirasi dan pengaduan masyarakat, danl memberikan pertanggungjawaban secaral moral dan politis kepada masyarakat kepada masyarakat di daerah yng diwakilkannya.

Sementara itu, undang-undang yang mengatur mengenau hak para anggota DPD tercantum dalam Pasal 257 Undang-Undang MD3. Dalam pasal tersebut, diatur pula mengenai beberapa hak dari anggota DPD, dan yang berkaitan dengan nilai demokrasi ialah mengenai hak memilih dan dipilih. Hak memilih merupakan hak yangg dimiliki oleh setiap warga negara unutk memilih para anggota legislatif berdasarkan hati nuraninya masing-masing. Sementara itu, hak dipilih merupakan hak yang dimiliki oleh setiap warga negara untuk menjadi calon anggota legislatif dan berhak dipilih sesuai dengan pilihan rakyat. Apabila dikaitkan dengan keadaan pencalonan perseorangan peserta pemilu anggota DPD, maka demokrasi tersebut merupakan salah satu partisipasi dari rakyat dalam 
menentukan pilihan calon legislatifnya maupun partisipasi rakyat untuk mencalonkan diri sebagai perwakilan aspirasi dari daerah provinsinya dalam perumusan, pengembangan, dan pembuatan hukum.

Dengan adanya aturan-aturan mengenai segala persyaratan tersebut, maka secara tidak langsung hal tersebut telah menciptakan kepastian hukum dalam masyarakat terkait persyaratan calon anggota DPD. Kepastian merupakan suatu keadaan yang sifatnya pasti. Kepastian itu hukum merupakn jamiman mengenao hukum yang berisi keadilan. Norma yang memajukan keadilan harus sungguh-sungguh berfungsi sebagai peraturan yang ditaati. Menurut Gustav Radbruch, keadilan dan kepastian hukum merupakan bagian yang tetap dari hukum. ${ }^{9}$ Dengan adanya kepastian hukum tersebut, masyarakat menjadi mengetahui boleh atau tidaknya dirinya mecalonkan diri sebagai anggota DPD berdasarkan apa yang telah diatur dalam UndangUndang Nomor 7 Tahun 2017 tentang

9 Achmad Ali, Menguak Tabir Hukum, (Jakarta: Toko Gunung Agung, 2002), hal. 82-83.
Pemilihan Umum dan Peraturan KPU Nomor 14 Tahun 2018 tentang Pencalonan Perseorangan Peserta Pemilu Anggota DPD mengenai persyaratannya.

\section{B. Analisis Kepastian Hukum}

Berdasarkan Kewenangan Lembaga

Terkait Pecalonan Pesreorangan Peserta Pemilu Anggota DPD

Seperti yang sudah diketahui, Mahkamah Agung dan Mahkamh Konstitusi memilikil tugas dan wewenang yng berbeda-beda. Semua tugas dan kewenangannya itu telah diatur secara jelas dalam UUD NRI 1945 maupun dalam undang-undang lainnya yang bersangkutan. Mengenai wewenang yang dimiliki Mahkamah Agung itu telah diatur di Pasal 24A Ayat (1) UUD NRI 1945 yang menyebutkan kalua wewenang Mahkamh Agug ialah mengadili pada tingkat kasasi, menguji peraturan perundang-undangan di bawah undang-undang terhadap undangundang, dan mempunyai kewenangan lain yng diberikan undang-undang. Selain itu, kewenangan Mahkamah 
Agung juga diatur dalam Pasal 28 Ayat (1) Undang-Undang Nomor 14 Tahun 1985 tentang Mahkamah Agung (yang selanjutnya disebut dengan Undang-Undang Mahkamah Agung) yang menyebutkan beberapa tugas dan wewenang dari lembaga tersebut, yaitu berupa memeriksa dan, memutus permohonan kasasi, sengketa tentang kewenangan mengadli, permohonan peninjaaun kembali putusan pengadilan yang telah memperoleh kekuatan hukum tetap, dan pengujian peraturan perundang-undangan di bawah undang-undang terhadap undangundang.

Sementara itu, mengenai kewenangan Mahkamah Konstitusi menurut Pasal 24C Ayat (1) UUD NRI 1945, yaitu mengadli di tingkt pertama dn trakhir ynag menguji lundang-undang terhadap UUD NRI 1945, memutus sengketa kewenangan lembaga negara yang kewenangannya diberikan oleh UUD NRI 1945, memutus pembubaran partail politik, dan memutus perselisihn tentang hasil pemilihanl umum. Kewenangan Mahkamah Konsttiusi yang disebutkan didalam Pasal 24C Ayat (1) UUD NRI 1945 sama halnya dngan yang disebutkan dalam Pasal 10 Undang - Undang Mahkamah Konstitusi.

Menurut Bapak Muhidin, pada mulanya Mahkamah Konstitusi didesain secara khusus yang bertujuan untuk melakukan judicial review dalan hal menguji konstitusionalitas suatu undang-undang terhadap UUD NKRI 1945. Lalu, hasil dari putusan Mahkmah Konstitusi tersebut dikatakan bersifat final dan pernyataan tersebut telah diatur dalam Pasal 10 Undang-Undang Mahkamah Konstitusi. Maksud dari kata final berarti tidak ada upaya hukum banding lainnya. Berbeda dengan peradilan lain yang memiliki upaya lain. Sifat final dalam putusan Mahkmah Konstitusi mencakup pula kekuatan hukun mengikat sebagaimana yang diatur dalam Pasal 47 Undang-Undang Mahkmah Konstitusi. Sifat mengikat bermakna bahwa pUtusan Mhkamah Konstitusi 
tidak hanya berlaku bagi para pihak saja, tapi jga berlaku bagi seluruh rakyat Indonesia. Oleh sebab itu, antara Pasal 10 Undang-Undang Mahkamah Konstitusi dengan Pasal 47 Undang-Undang Makamah Konstitusi memiliki keterkaitan tentang sifat dari putsan Mahkamah Konstitusi. Sementara itu, putusan Mahkamah Agung juga bersifat final, namun putusan Mahkamah Agung masih dapat dilakukan upaya hukum, yaitu berupa peninjauan kembali putusan pengadilan yang telah memperoleh kekuatan hukum tetap. ${ }^{10}$

Selain perbedaan pada upaya hukumnya, perbedaan lainnya juga terletak pada objek perkaranya. Pengujian Mahkamah Agung terletak pada peraturan perndang-undagan di bawah undang-undang terhadap undang-undang. Artinya, Mahkamah Agung bukan menguji konstitusionalitasnya, tapi menguji legalitas. Menguji legalitas berarti menguji telah sesuainya atau belum

\footnotetext{
${ }^{10}$ Wawancara langsung dengan Bapak Muhidin, S.H., M.H., Panitera Muda II Mahkamah Konstitusi pada hari Senin, 6 Mei 2019, pukul 14.00 WIBdi Ruangan Lantai 11 Mahkamah Konstitusi.
}

sebuah peraturan perundang-undangan tersebut. Sementara itu, Mahkamah Konstitusi mempunyai level yang lebih tinggi karena Mahkamah Konstitusi melakukan pengawasan terhadap konstitusi. Sebab, Indonesia menganut teori hierarki, sehingga peraturan perundang-undangan yang lebih rendah tdak boleh bertentangan dengan peraturan yang lebih tinggi. Idealnya, antara putusan Mahkamah Agung dan putusan Mahkamahl Konstitusil itu tidak melahirkan hasl yang berbeda. Sebab, dengan lahirnya 2 (dua) putusan yang berbeda dari lembaga yudikatif, maka dapat menyebabkan sebuah permasalahan baru dalam masyarakat. Namun, faktanya masih banyak ditemukan tidak selarasnya antara putusan Mahkamah Agung dan putusan Mahkamah Konstitusi.

Pernyataan di atas terbukti dengan adanya perbedaan antara putusan Mahkamah Agung dan putusan Mahkamah Konstitusi terkiat masalah pencalonan perseorangan peserta pemilu anggota DPD. Berdasarkan yang 
telah Penulis paparkan di bab sebelumnya, perbedaan atau permasalahannya terletak pada boleh dan tidaknya calom anggota DPD yang berasal dari kepengurusan partai politik. Dalam Putusan Mahkamah Agung Nomor 65P/HUM/2018, dikatakan bahwa calon anggota DPD boleh berasal dari kepengurusan partai politik. Hal tesebut jelas berbeda dengan hasil dari Putusan Mahkamh Konstitusi Nomor 30/PUU-XVI/2018 yang melarang calon anggota DPD berasal dari kepengurusan partai politik.

Lahirnya Putusan Makamah Kostitusi Nomor 30/PUU-XVI/2018 merupakan dari hasil judicial review Undang-Undang Nomor 7 Tahun 2017 tentang Pemilihan Umum terhadap UUD NRI 1945. Judicial reiview merupakan suatu pengujian norma terhadap peraturan perundangundangan oleh lembaga peradilan terhadap produk hukum yang dihasilkan oleh lembaga legislatif. Objek materil dalam judicial review tersebut adalah mengenai frasa "pekerjaan lain” yang dianggap tidak memiliki kepastian hukum. Cara yang dapat dilakukan untuk dapat memahami lebih dalam terkait frasa "pekerjaan lain" dalam persyaratan pencalonan anggota DPD, ialah dengan melakukan sebuah penafsiran. Berdasarkan penafsiran tekstual, yaitu sebuah penafsiran yang dilakukanl dengn cara memberikam maknal terhadap arti dari kata - kata di dalam dokumen atau teks yng diibuat oleh lembaga legislatif. ${ }^{11}$ Dalam hal ini, makna frasa "pekerjaan lain" tersebut secara tekstual ialah pekerjaan yag dpat mengakibatkan konflik kepentingan dengan tugas, wewenang, dan hak sebagai anggota DPD sesuai dengan ketentuan peraturan perundang - undangan. Dalan memutuskan makna frasa "pekerjaan lain” tersebut, Mahkamah Konstitusi secara sistematis berlandaskan pada konstitusi dan undang-undang lainnya yang berkaitan dengan persyaratan pencalonan anggota DPD. Secara

\footnotetext{
${ }^{11}$ Tim Penyusun Hukum Acara Mahkamah Konstitusi, Hukum Acara Mahkamah Konstitusi, (Jakarta: Sekretariat Jenderal dan Kepaniteraan Mahkamah Konstitusi Republik Indonesia, 2010), hal. 74 .
} 
sistematis, yaitu merupakan penafsiran undng - undang sbagai bagian dari keseluruhan sistem perundang undagan dengn cara menghubungkan undng - undang yang satu dengn undang - undang yang lain. ${ }^{12}$

Tujuan diaturnya mengenai larangan calon anggota DPD berasal dri kepengurusan partai politik disebabkan karena hal tersebut dapat menyebabkan perwakilan ganda. Dengan kata lain, hal tersebut dapat menyebabkan benturan kepentingan antara yng saut dengan yang lainnya. Sebab, masing - masing lembaga tersebut mempunyai tugas dan wewenang yang berbeda, sehingga tidak dapat disatukan. Sesungguhnya, dengan adanya seluruh undang-undang maupun peraturan yang mengatur mengenai persyaratan calon anggota DPD seharusnya sudah jelas. Jadi, apabila ingin mencalonkan diri sebagai perseorangan peserta pemilu anggota DPD, maka harus terlepas dari kepengurusan partai politik. Sebab secara konstitusi, dibentuknya

12 Sudikno Mertokusumo dan A. Pitlo, Penemuan Hukum, (Bandung: Citra Aditya Bakti, 1993), hal. 16-17. pemisahan antara lembaga DPR dan DPD bertujuan untuk menghindari penyalahgunaan wewenang maupun penyalahgunaan jabatan. Dengan adanya lembaga DPR dan DPD, maka masing - masing tugas dan wewenang memiliki posisinya masing - masing, sehingga tidak dapat dicampur adukan. Lembaga DPR dibentuk dengan tujuan untuk sebagai wadah penampung aspirasi rakyat yang kemudian dilanjutkan kepada pemerintah pusat. Sementara itu, dibentuknya lembaga DPD bertujuan untuk menampung aspirasi dari masing - masing daerah yang kemudian dilanjutkan ke pemerintah pusat. Oleh sebab itu, komposisi anggota dari masing masing lembaga tersebut tidak dapat dijadikan satu. Anggota DPR terdiri dari anggta - anggota partai politik pesertla pemilihan umum yang dipilih melalui pemilihan umum. Sementara itu, anggota DPD terdiri dri anggota perwakilan dari setiap provinsi yang dipilih melalui pemilihan umum dan bukan dri partai politik.

Secara konstitusi, lembaga DPD bertujuan untuk lebih dapat 
mengembangkan aspirasi - aspirasi daerah supaya terciptanya wadah dlam menyuarakan kepentingannya dalm sistem ketatanegaran Indonesia. Wadah tersebut nantinya dapat digunakan sebagai sarana yang dapat mengomunikasikan antara pusat dengan masing - masing daerah. Dengan adanya wadah tersebut diharapkan mampu menyelaraskan kepentingan pusat dengan kepentingan di daerah - daerah. Dengan begitu, maka kesatuan di daerah - daerah dalam kerangka NKRI dapat semakin kokoh. Sejalan dengan pendapat dari Bapak Ahmad Redi, menurut beliau anggota DPD memang harus murni dari intervensi partai politik. Apabila perorangan peserta pemilu anggota DPD tersebut masih mempunyai tanggung jawab dalam kepengurusan partai politik, maka lebih baik perorangan tersebut mencalonkan diri sebagai anggota DPR saja yang memang terdiri dari para politisi. ${ }^{13}$ Jika dilihat berdasarkan sistem

\footnotetext{
${ }^{13}$ Wawancara langsung dengan Bapak Dr. Ahmad Redi, S.H., M.H., Ahli Hukum Tata Negara dan Dosen Fakultas Hukum Universitas Tarumanagara pada hari Selasa, 7 Mei 2019, pukul 09.30 WIB di Ruangan 407 Gedung M Universitas Tarumanagara.
}

ketatanegaraan, kekuasaan kehakiman di Indonesia terbagi menjadi 3 (tiga) cabang, yaitu legislatif, eksekutif, dan yudikatif. Pemisahan kekuasaan mrupakan pemisahan yang dilakukan scara fungsional terhadap kekuasaan negara dan bersifat horizontal yng trdiri dri kekuasaan legislatif, eksekutif, dan yudikatif. ${ }^{14}$ Kekuasan legislatif adalah kekuasaan untuk membntuk sebuah undang-undang. Kekuasaan eksekutif ialah kekuasaan kekuasaan untuk melaksanakan undang - undang. Kekuasaan yudikatif merupakan kekuasaan untuk mengadili atas terjadinya pelanggaran tehadap undang undang. ${ }^{15}$ Ketiga kekuasaan tersebut tidak dapat dipisahkan dalam pelaksanaannya karena ketiga kekuasaan tersebut saling berkaitan, saling mengawasi serta saling mengimbangi.

\section{Berkaitan dengan pembagian} cabang kekuasaan kehakiman tersebut, maka lembaga MPR, DPR, dan DPD termasuk dalam cabang kekuasaan

\footnotetext{
${ }^{14}$ Miriam Budiarjo, Dasar-Dasar Ilmu Politik, (Jakarta: Gramedia Pustaka, 2009), hal. 151.

${ }^{15}$ Sri Soemantri, Hak Menguji Materil di Indonesia, (Bandung: Alumni, 1997), hal. 75.
} 
legislatif. Oeh sebabnya, maka hal ini juga berkaitan dengan teori lembaga perwakilan rakyat, di mana lembaga perwakilan rakyat dalam sistem ketatanegaraan di Indonesia terbagi menjadi 4 (empat), yaitu MPR, DPR, DPD, DPRD Provinsi dan DPRD Provinsi Kabupaten/Kota. Kehadiran seorang wakil dalam sebuah lembaga perwakilan, baik karena pengangkatan maupun pemilihan umum dapat mengakibatkan timbulnya hubungan antara si wakil dan yang diwakilkan. ${ }^{16}$ Dengan adanya pemisahan terhadap lembaga tersebut, diharapkan dapat terciptanya keseimbangan dalam menjaga akuntabilitas penyelenggara negara dalam menjalankan roda pemerintahan. Selain itu juga berfungsi untk salng mengawasi antara satu lembaga dngan lembaga lainnya, sehingga setiap lembaga negara tersebut memiliki peran yang seimbang. Hal ini juga diperkuat dengan pendapat dari Bpak Pan Mohamad Faiz yang menyatakan

${ }^{16}$ Sirajuddin dan Winardi, Dasar-Dasar Hukum Tata Negara Indonesia, (Malang: Setara Press, 2015), hal. 92. apabila fungsi DPD tidak segara dikembalikan pada koridor konstitusionalnya, maka besar kemungkinan di masa yang akan datang fungsi DPD akan tercampur aduk dengan fungsi lainnya. Hal tersebut nantinya dapat mengakibatkan tidak efektifnya peran dan fungsi lembaga perwakilan dalam memperjuangkan aspirasi daerah. ${ }^{17}$ Tercampur aduknya fungsi dari masing-masing lembaga tersebut itulah yang dikhawatirkan oleh masyarakat.

Dalam Pasal 474 Ayat

Undang-Undang Nomor 7 Tahun 2017 tentang Pemilihan Umum, disebutkan bahwa Komisii Pemilihn Umum wajib menindaklanjuti putusan Mahkamah Konstitusi. Oleh sebab itu, sebagai wujud menindaklanjuti putusan Mahkamah Konstitusi tersebut, maka KPU mengeluarkan Peraturan Komisi Pemilihan Umum Nomor 26 Tahun 2018 tentang Pencalonan Perseorangan Peserta Pemilu Anggota

17 Pan Mohamad Faiz, "Sengkarut Syarat Calon Anggota DPD", https://panmohamadfaiz.com/2019/01/10/sengkarutsyarat-calon-anggota-dpd/, diakses pada tanggal 9 Juni 2019, pukul 12.55 WIB. 
DPD. Setelah lahirnya Peraturan

Komisi Pemilihan Umum tersebt, Mahkamh Agung mengeluarkan putusan dengan nomor 65P/HUM/2018 yang merupakan permohonan uji materil dari ketua umum salah satu partai politik di Indonesia, yang bernama Oesman Sapta Odang (OSO). Dalam pertimbangannya, Mahkmah Agung menilai bhwa Perturan KPU tersebut berlaku surut mengenai ketentuan persyaratan calon anggota DPD dan dalam putusannya Mahkamah Agung membolehkan calon anggota DPD yang berasa dari kepengurusan partai politik.

Menurut salah satu peneliti senior Mahkamah Konstitusi, Bapak Pan Mohamad Faiz, dalam tulisannya ia menyatakan bahwa untuk mengetahui benar atau tidaknya Peraturan Komisi Pemilihan Umum tersebut dinilai berlaku surut, maka dapat dilakukan analisis secra kronologis terhadap tahapan pecalonan anggota DPD untk pemilu 2019. Secara analisis kronologis, Peraturan Komisi Pemilihan Umum dapat dinilai sudah tepat karena keputusan Komisi Pemilihan Umum mengenai Daftar Calon Sementara (DCS) dn Daftar Calon Tetap (DCT) scara normatif keduanya dikeluakan pasca dijatuhkannya ptusan Mahkamah Konstitusi dngan didsarkan pda Peraturan Komisi Pemilhan Umum yang telah diubah demi menjalankan Putsan Mahkmah Konstitusi Nomor 30/PUU-XVI/2018. Di samping itu juga, persyaratan calon anggota DPD yang melarang calon anggotanya dari kepengurusan partai politik telah diatur sejak awal secara jelas dalam undang - undang. Seperti dalam Psal 63 huruf b Undang - Undang Nomor 12 Tahun 2003 tentang Pemilihan Umum Anggota Dewan Perwakilan Rakyat, Dewan Perwakilan Daerah, Dewan Perwakilan Rakyat Daerah menybutkan bahwa calon anggota DPD selain harus memenuhi syarat calon sebagaimana yang tercantum dalan Pasl 60, calon anggota DPD jga dilarang mnjadi pengrus partia politik sekurang - kurangnya 4 (empat) tahun yang dihtung sampai dngan 
tnggal pengajuan calon. Selain itu, larangan serupa sudah pernah diputus dalam Putusan Mahamah Konstitusi Nomor 10/PUU-VI/2008. Dalam pertimbangan hukumnya, Mahkamah Konstitusi menyebutkan bahwa apabila calon perseorangan dan/atau anggota DPD juga beraktifitas kesehariannya sebagai pengurus partai politik, maka akan menjadi tidak terhindarkan terjadinya benturan kepentingan. Benturan kepentingan tersebut dapat berujung pada berubahnya original intent pembentukan DPD sebagai representasi daerah. Jadi sesungguhnya larangan mengenai calon anggota DPD yang tdak bolh brasal dari kepengurusan partai politik sudah diatur dengan jelas di dalam undang-undang sebelumnya. Semuanya sudah diatur secara sistematis dan terstruktur dengan cara mengaitkan undang-undang yang satu dengan yng laiin. Dalam hal ini, bukan berarti pihak Mahkamah Konstitusi maupun Komisi Pemilihan Umum memiliki niat untuk menjatuhkan salah satu pihak dalam pencalonan perseorangan peserta pemilu anggota DPD 2019. Selain sudah diaturnya larangan tersebut, Mahkamah Konstitusi dan Komisi Pemilihan Umum telah memberikan kesempatan bagi yag bersangkutan utuk masih bisa mencalonkan diri sebagai anggota DPD, apabila yang bersangkutan telah membuat surat pemberhentian dari kepengurusan partai politik sampai tanggal yang telah ditetapkan. Berkaitan dengan permasalahan ini, seharusnya judicial review yang dilakukan di Mahkamah Agung dihentikan. Sebab, isu hukumnya sama dengan isu hukum yang diuji oeh Mahkamah Konsltitusi. Di mana dalam hal ini Mahkamah Konstitusi tlah dengan tegas memutus terkait persyaratan calon anggota DPD, yang salah satunya membahas mengenai frasa "pekerjaan lain” yang termask pekerjaan sebagai kepengurusan partai politik. Berkaitan pendapat dari Bapak Muhidin, sebetulnya pengaturan tersebut telah diatur dalm Pasal 55 Undang - Undang Mahkamah Konstitusi yang 
menyatakn bahwa pengujian

peraturan perundang - undangan di bawah undang - undang yng sedng dilakukan Mahkamah Agung wajib dihentikan apabila undang-undang yang mejadi dasar pengujian peraturan trsebut sdang dalam proses pengujian Mahkamah Konstitusi. Dalam konteks ini, seharusnya Mahkamah Agung tidak menguji kembali isu hukum yang sama dengan pengujian yang ldilakukan oleh Mahkamah Konstitusi, karena tujuannya adalah untuk menghindari hasil putusan yang berbeda. ${ }^{18}$

Dari penjelasan di atas, maka kepastian hukum 2 (dua) putusan dari lembaga peradilan ini dipertanyakan. Menurut Bapak Ahmad Redi, demi terciptanya hasil putusan yang selaras antar lembaga kekuasaan kehakiman, idealnya uji materil lebih baik dilakukan dalam one roof system (sistem satu atap). Jadi alangkah baiknya, proses pengujian materil terhadap seluruh peraturan perundang

\footnotetext{
${ }^{18}$ Wawancara langsung dengan Bapak Muhidin, S.H., M.H., Panitera Muda II Mahkamah Konstitusi pada hari Senin, 6 Mei 2019, pukul 14.00 WIBdi Ruangan Lantai 11 Mahkamah Konstitusi.
}

-undangan dari UUD NRI 1945 sampai undang-undang di bawah UUD NRI 1945 dilakukan oleh satu lembaga kekuasaan kehakiman. Lembaga kekuasaan kehakiman yang direkomendasikan adalah Mahkamah Konstitusi, karena proses sidang di Mahkamah Konstitusi lebih terbuka dibandingkan proses sidang di Mahkamah Agung. Biarkan Mahkamah Konstitusi saja yng menguji seluruh peraturan perundang - undangan, baik undang - undang terhadap UUD NRI 1945 maupn peraturan perundang-undangan yang di bawah undang-undang.

Sejalan dengan pendapat dari Bapak Ahmad Redi, Penulis berpendapat bahwa dalam melakukan uji materil dalam sistem satu atap merupakan solusi terbaik. Lembaga yang direkomendasikan ialah Mahkamah Konstitusi. Pengujian dengan sistem satu atap tersebut bertujuan untuk menghindari lahirnya putusan yang bersifat memiliki makna yang berbeda - beda sehingga dapat menyebabkan ketidakpastian hukum dan kesimpangsiuran dalam 
masyarakat. Sebab, tidak semua hakim dapat mengetahui semua informasi mengenai materi maupun informasi mengenai hal akan di sidangkan. Dalam konteks hukum, lahirnya putusan yang berbeda dari kedua lembaga tersebut sesungguhnya sahsah saja, apalagi hakim yang memutus berasal dari lembaga yang berbeda. Kedua lembaga peradilan tersebut memiliki kewenangannya masing masing yng telah diatur di dalam undang - undang dan UUD NRI 1945. Selain itu, dalam Pasal 24 UUD NRI 1945 disebutkan bahwa kekuasaan kehakiman merupakan kekuasaan yang merdeka. Artinya, Hakim Agung dan Hkim Konstitusi bebas dalam memutus sebuah perkara berdasarkan pertimbangannya dan sesuai dengan apa yang dipikirkan oleh para hakim. Namun, jika lahirnya dua putusan yang berbeda antara Mahkamah Agung dan Mahkamah Konstitusi, maka putusan yang harus diikuti adalah putusan Mahkamah Konstitusi. Sebab jika dilihat dari jenisnya, Mahkamah Konstitusi berwenang dalam hal memeriksa dan memutus sebuah undang -undang terhadap UUD NRI 1945. Oeh sebab itu, level putusan Mahkamah Konstitusi itu setara dengan sebuah undang-undang walaupun putusan Mahkamah Konstitusi tidak termasuk dalam hierarki peraturan perundang undangan. Berbeda halnya dengan putusan Mahkamah Agung yng menguji peraturan perundang undangan di bawah undangg - undng terhadpa undang-undang.

Terhadap semua penjelasan yang telah dipaparkan di atas, Penulis berpendapat bahwa lahirnya Putusan Mahkamah Agung Nomor 65P/HUM/2018 yang berbeda dengan Putusan Mahkamah Konstitusi Nomor 30/PUU-XVI/2018 mengakibatkan kesimpangsiuran hukum dalam masyarakat. Masyarakat maupun lembaga lain bingung dalam menentukan sikap terhadap 2 (dua) putusan yang berbeda tersebut. Sebab, antara Mahkamah Agung dan Mahkamah Konstitusi merupakan 2 (dua) lembaga peradilan yang sederajat, hanya saja tugas dan kewenangannya yang berbeda. Dengan 
begitu berdasarkan seluruh penjelasan yang telah dipaparkan sebelumnya, maka dalam permasalahan di penelitian ini dapat dikatakan bahwa putusan yang memiliki kepastian hukum terkait masalah pencalonan perseorangan peserta pemilu anggota DPD adlah Putusan Mahkamah Konstitusi Nomor 30/PUU-XVI/2018.

\section{PENUTUP}

\section{A. Kesimpulan}

Berdasarkan pembahasan yang telah dipaparkan, maka dapat ditarik kesimpulan bahwa lahirnya putusan yang berbeda dari Mahkamah Agung dan Mahkamah Konstitusi dapat dikatakan sah-sah saja. Sebab, keduanya memiliki wewenang dalam melakukan judicial review. Dengan munculnya 2 (dua) hasil putusan yang berbeda tersebut, sudah seharusnya kita mengikuti hasil putusen Mahkamah Konstitusi. Sebab, putusan Mahkamah Konstitusi merupakan hasil dari pengujian undang - undang terhadap UUD NRI 1945. Jadi putusan
Mahkamah Konstitusi memiliki level yang sederajat dengan undang - undang walaupun tidak termasuk dalam hierarti peraturan perundang undangan.

Selanjutnya, terkait pernyataan Peraturan Komisi Pemilihan Umum No 26 Tahun 2018 yang dinilai berlaku surut adalah tidak tepat. Sebab, dalam analisa kronologi tahapan tersebut, keputusan Komisi Pemilihan Umum mengenai Daftar Calon Sementara (DCS) dan Daftar Calon Tetap (DCT) secara normatif keduanya dikeluarkan pasca dijatuhkannya putusan Mahkamah Konstitusi dengan didasarkan pada Peraturan Komisi Pemilhan Umum yang telah diubah demi menjalankan Putusan Mahkamah Konstitusi Nomor 30/PUU-XVI/2018.

Di samping itu, pengaturan mengenai persyaratan anggota DPD sesungguhnya telah diatur dalam undang - undang maupun putusan Mahkamah Konstitusi terdahulu. Di dalam Pasal 63 huruf $b$ UndangUndang No 12 Tahun 2003 tentang Pemilihan Umum Anggota Dewan 
Perwakilan Rakyat, Dewan

Perwakilan Daerah, Dewan

Perwakilan Rakyat Daerah yang menyatakan calon anggota DPD dilarang menjadi pengurus partai politik sekurang - kurangnya 4 (empat) tahun yang dihitung sampai dengan tanggal pengajuan calon. Selain itu, larangan calon anggota DPD yang berasal dari kepengurusan partai politik juga sudah diatur dalam Putusan Mahkamah Konstitusi No 10/PUU-VI/2008. Di mana di dalam pertimbangan hukumnya. Di mana dalam pertimbangan hukumnya dikatakan bahwa apabila calon perseorangan dan/atau anggota DPD juga beraktifitas sehari-hari sebagai pengurus partai politik, maka dapat menyebabkan terjadinya benturan kepentingan. Berkaitan dengan hal tersebut, maka dapat dinilai bahwa Mahkamah Agung keliru dalam memeriksa dan memutus perkara persyaratan calon anggota DPD. Mahkamah Agung dinilai kurang mendapatkan informasi -informasi seputar persyaratan calon anggota DPD yang sesungguhnya telah diatur dalam undang - undang maupun putusan Mahkamah Konstitusi yang berkaitan dengan persyaratan calon perorangan anggota DPD.

\section{B. Saran}

Dengan masih banyaknya ditemukan perbedaan hasil dari putusan - putusan dari Mahkamah Agung dan Mahkamah Konstitusi, maka perbedaan tersebut dapat menimbulkan ketidakpastian hukum dalam masyarakat. Adapun saran yang dapat diberikan oleh Penulis dalam penelitian ini ditujukan kepada pemerintah untuk dapat dilakukannya sistem satu atap (one roof system), yaitu proses pengujian materil terhadap keseluruhan peraturan perundang - undangan dari UUD NRI 1945 sampai undangundang di bawah UUD NRI 1945 dilakukan oleh satu lembaga kekuasaan kehakiman saja. Biarkan satu lembaga kekuasaan kehakiman tersebut yang melakukan pengujian seluruh peraturan perundang undangan, baik undang-undang terhadapa UUD NRI 1945 maupun 
peraturan perundang-undangan yang di bawah undang - undang. Lembaga kekuasaan kehakiman yang direkomendasikan adalah Mahkamah Konstitusi. Sebab, dalam proses sidang Mahkamah Konstitusi itu lebih terbuka dibandingkan proses sidang di Mahkamah Agung. Selanjutnya, untuk kedepannya bagi semua lembaga peradilan di Indonesia dapat secara teliti dalam melakukan pengujian undang-undang maupun peraturan perundang - undangan lainnya maupun dalam hal memeriksa dan memutus. Selain itu, diharapkan seluruh masyarakat dapat mentaati segala ketentuan - ketentuan yang tertuang dalam perundang - undangan dan menghormati masing - masing kompetensi tiap peradilan.

\section{DAFTAR PUSTAKA}

\section{A. Buku}

Sirajuddin dan Winardi. Dasar-Dasar

Hukum Tata Negara Indonesia.

Malang: Setara Press, 2015.

Handoyo, B. Hestu Cipto. Hukum Tata

Negara Indonesia. Yogyakarta:

Universitas Atma Jaya

Yogyakarta, 2009.
Huda, Ni'Matul. Hukum Tata Negara

Indonesia. Jakarta: Raja

Grafindo, 2005.

Marzuki, Peter Mahmud. Penelitian

Hukum. Jakarta: Kencana

Prenada Media Group, 2016.

Mertokusumo, Sudikno dan A. Pitlo.

Penemuan Hukum. Bandung:

Citra Aditya Bakti, 1993.

Tim Penyusun Hukum Acara Mahkamah

Konstitusi. Hukum Acara

Mahkamah Konstitusi. Jakarta:

Sekretariat Jenderal dan

Kepaniteraan Mahkamah

Konstitusi Republik Indonesia, 2010.

Tunjung Herming Sitabuana.

Penyelesaian Masalah

Diskriminasi Terhadap Etnis

Cina (Studi Tentang

Perkembangan Politik Hukum di

Bidang Kewarganegaraan

Republik Indonesia). Ringkasan

Disertasi Doktor, Universitas

Diponegoro, 2011.

\section{B. Artikel Jurnal Online}

Faiz, Pan Mohamad. "Serangkut Syarat Calon Anggota DPD'. https://panmohamadfaiz.com/20 19/01/10/sengkarut-syaratcalon-anggota-dpd/. Diakses 
Rasji \& Cinthia

Volume 17, No. 1, Juni 2019

Kepastian Hukum Mengenai Perbedaan...

pada tanggal 9 Juni 2019, 12.55

WIB.

Indonesia Tahun 2009

Nomor 157, Tambahan

Lembaran Negara Republik

C. Perundang-undangan

Indonesia, Undang-Undang Dasar

Indonesia Nomor 5076).

Negara Republik Indonesia

Tahun 1945.

. Undang-Undang Nomor 14

Tahun 1985 tentang

Mahkamah Agung

(Lembaran Negara Republik

Indonesia Tahun 1985

Nomor 73, Tambahan

Lembaran Negara Nomor 1985).

\section{Putusan}

. Undang-Undang Nomor 24

Indonesia. Putusan Mahkamah

Tahun $2003 \quad$ tentang

Mahkamah Konstitusi

Konstitusi Nomor 30/PUU-

XVI/2018.

(Lembaran Negara Republik

Indonesia Tahun 2003 . Putusan Mahkamah Agung

Nomor 98, Tambahan Nomor 65P/HUM/2018.

Lembaran Negara Republik

Indonesia Nomor 4317).

Undang-Undang Nomor 48

Tahun 2009 tentang

Kekuasaan Kehakiman

(Lembaran Negara Republik 